\title{
13. Evidentiary Issues with the Implementation of the Sustainability Duty of Care in the Basin Plan
}

\author{
Jennifer McKay
}

\section{Introduction}

This chapter explores some of the possible legal ramifications of implementing the sustainability duty of care in the Murray-Darling Basin Plan. Australia- having pushed to the limits all available power bases in the Federal Constitution - was able to achieve a political settlement with the States in 2008. This enabled the Federal government to use power refered from the States under section 51(37) of the Constitution. These unique sets of legal arrangements were marshalled to enact the Water Act 2007 with its requirements to draft the first Basin Plan for sustainable diversion of surface and groundwater in the Murray-Darling Basin (MDB) area of four States. The Basin Plan will be known as the Murray-Darling Basin Plan. The Guide to the proposed Basin Plan (released in October 2010) is the locus for community consultation on 'the quality of the data and evidence used and the analyses undertaken' (MDBA 2010:ix).

These political accommodations to create the Water Act and the Basin Plan occurred during the final year of a decade of drought and after the patchy implementation of two previous Federal Government initiatives: by the Council of Australian Governments (COAG) in 1994 and in 2004-both known as the National Water Initiative (NWI). The Water Act 2007 places a sustainability duty of care and imbeds innovative standards of care in one law - in Section 21 -applicable to all State governments in relation to sustainable diversion of surface and groundwater. The sustainability duty is expressed as the following: 'to achieve the national interest and the standard of care is to...implement relevant international agreements and to achieve ESD' as defined in Section 4(2). The duty is imposed on each State to draft regional water plans to achieve the sustainability duty, and then the Murray-Darling Basin Authority (MDBA) is empowered to accredit or adopt these- or not-according to the above standards.

This chapter will examine issues in the most potentially litigious areas of dispute in relation to the sustainability duty and standard of care. It will look at how a plaintiff may discharge the burden and the social conflicts that might be 
generated between different stakeholders. It will consider sustainable diversion limits (SDLs), and the tests around national interest and relevant international agreements, and will consider legal evidentiary issues in all three.

It concludes that a duty to cooperate needs to be inserted in the Water Act 2007, and that the power to do this would come from inter alia relevant international agreements such as the 1997 UN Watercourses Convention and the recent International Law Commission's Transboundary Aquifer articles. This duty would apply to the States in the drafting of their water plans. Such a duty should also be inserted in relevant State laws to apply to landholders.

\section{The Sustainability Duty of Care in the Water Act 2007 and the Guide to the proposed Basin Plan}

The Water Act 2007 created an independent body - the Murray-Darling Basin Authority (MDBA) - and charged it with developing a Basin Plan for the consideration of the relevant Commonwealth minister (MDBA 2010). The sustainability duty of care was expressed as: 'the Authority is to determine the volume of water required to maintain and restore environmental assets, using best available science and the principles of ecologically sustainable development. Subsequently, the Authority addressed the optimisation of environmental, social and economic outcomes' (MDBA 2010:iii).

This was built on earlier reforms, and in fact embeds the 2004 COAG reforms known as the NWI. These punctuated and hence changed the State governments' introspective water use, management cultures and law regimes (McKay 2010). The pre-existing introspective State law regimes have been weakly cooperative, and they promoted economic and social development.

These law regimes were punctuated with requirements for the achievement of ecologically sustainable development. This was a broad requirement. The various State law formulations included: the precautionary principle; inter and intra generational equity; integration of long and short-term environmental, economic and social considerations; water plans in regions; separation of water from land to create water markets; incorporation of the private sector in water supply; environmental allocations in water plans to maintain the health and viability of river systems and groundwater basins (COAG 1994:Attachment A Clause 4[d]; Commonwealth of Australia 2004); capacity sharing of consumptive pools of water (after environmental needs have been catered for); and full cost recovery. The 2004 reforms were specific and required improved environmentalmanagement practices, completely returning all currently over-allocated or 
overused systems to environmentally sustainable levels of extraction and managing surface and groundwater as a single source. The NWI defined environmental outcomes as maintaining ecosystem function through periodic inundation of floodplains, wetlands biodiversity, water-quality and river-health targets (Commonwealth of Australia 2004:Schedule B).

The Water Act 2007 arose out of the dissatisfaction by the political leader of the day (Prime Minister, John Howard) with the implementation of the above reforms, despite financial incentives being used to drive reforms - that is, payment to the States for achieving the above. It is fair to say that there have always been disputes between the parties about the meaning of the terms in the NWI and also the Water Act 2007.

The Water Act 2007 was built, then, against a background where implementation issues were known to be a problem and the communication of science to the policy makers was fraught (Tomlinson and Davis 2010). Many of these problems arose from lack of knowledge but also from lack of coordination between the States. The Water Act 2007 continued, however, to be innovative and created several new terms, such as long-term sustainable diversion limits (SDLs). These are long-term average volumes of water that can be diverted for consumptive use (irrigation, town-water supplies, industry, and so on) after the environment has received what it requires (MDBA 2010:103). The Water Act 2007 (s. 23[1]) refers to this standard as the 'environmentally sustainable level of take', and it requires that this be established using the best available science, and also so that social, economic and environmental goals are met. The MDBA considers that the SDL is a judgment about how best to balance these requirements.

The Guide to the Proposed Basin Plan specified tat the reductions in take (interceptions and diversions) should be between 3,000 and 7.600 GL. It was recommended, however, that the reduction in take whould be no more than 4,000 GL because of socio-economic considerations. Even the 3,000GL proposed reduction resulted in considerable community angst and was also criticised for not taking into account social and economic effects (McKay 2010). The main dispute was over the assertions of projected job losses. The MDBA stated 800, but the NSW Farmers' Federation predicted a massive depopulation of the region. The MDBA took legal advice on the basis of the 3000 GL figure and suggested that this figure could be too high because of 'greater consideration of the social and economic needs of rural communities. This was welcomed by irrigators but left environmentalists fuming. The advice would force a review with less returned to the river for environmental purposes' (Ker 2010).

A key question is, how will these judgments be made? In a court case how will the words in the Water Act 2007 be interpreted and the judgments of the 
MDBA be evaluated? The evidentiary standard for SDLs is the best available science, which prima facie is a high objective standard and is one bound to cause controversy on the issues of 'best' and 'available'.

This term has been used in several US acts but not any other Australian acts. For example, in the United States, National Standard 2 of the MagnusonStevens Fishery Conservation and Management Act states that conservation and management measures shall be based on 'the best scientific information, available'. Further, the US Environmental Protection Agency (USEPA) has emphasised the role of best available science in implementing the Clean Water Act 1997 (Sullivan et al. 2006). US discussions of best available science include these factors

- a clear statement of objectives

- a conceptual model, which is a framework for characterising systems, making predictions, and testing hypotheses

- a good experimental design and a standardised method for collecting data

- statistical rigour and sound logic for analysis and interpretation

- clear documentation of methods, results, and conclusions

- peer review.

All of these issues may be litigated. The availability of science is a further complication. The MDB Guide was based on specially commissioned data and studies that were subsequently made available. Other sources of scientific knowledge are, however, clearly available through the Internet, and include refereed journal articles, grey literature and the opinions of experts.

The legal issues in the use of scientific evidence in courts have been discussed by Edmond and Mercer (1997) in relation to the weight judges should apply to the various types of scientific knowledge (such as above). The context discussed by Mercer was the judicial use of scientific evidence regarding causation of birth defects in the United States. In fact, the cases have ranked available scientific studies according to how they were generated-independently peer reviewed, replicated or produced for the litigation.

All of these considerations would be applied to any litigation taken by a State in relation to the Basin Plan and have already arisen in the several State cases on the scientific bases for litigation when State water plans have reduced the amount of water able to be allocated on ecologically sustainable development (ESD) grounds. The US courts recognised the primacy of published epidemiological studies (Dietz and Stern 1998; Edmond and Mercer 1997:666).

The judges will require some intellectual dexterity to wrestle with the content of the water plan and the complex range of science, such as epidemiological 
studies, which could result in litigation. As demonstrated by the US litigation cases, the choices made are amenable to a political analysis, and the level of the court, the issue and other considerations will be relevant.

\section{The ESD Implementation in State Water Plans and the Standard-of-Care Evidentiary Issues with Accreditation of State Water Plans}

An ESD standard has been placed in State laws that have required regional water plans in agricultural regions for several years. Under State laws, large water users such as individual companies are also required to produce waterefficiency plans (Gunningham and Sinclair 2010).

In many cases, there was social conflict between users in the regional waterplanning areas as plans had been drafted to implement reduced water allocations to achieve ESD. Hence, there has been considerable State litigation, which will assist the High Court and State Supreme Courts in dealing with these new issues. These decisions were, however, made under State laws with different formulations of the words used to describe the ESD standard. These decisions are not binding on the High Court, which will be hearing these matters under the Water Act.

The several decisions have tended to uphold the adoption of the science that suggests a river or aquifer is over-allocated. The courts have looked into the processes of notification and required natural justice to the water-holder but in the end have generally reduced the amount of water that an individual may hold - even if this would destroy their business. A case in point is Elandes in the Environment Resources and Development Court of South Australia (Elandes Nominees Pty Ltd vs Minister for Water Resources [2002] SAERDC 130), in which reduced allocations to achieve ESD in an aquifer meant that one grower had to leave the almond industry. Another case is Harvey in New South Wales, where the plan reduced water allocations by nearly 50 per cent in an aquifer. The dispute involved evidence on the quality of the science. The science was tested, and ultimately a scheme was devised to reduce water allocation not pro rata (as is common in decisions), but according to a scheme that recognised past use.

The Water Act incorporates a process whereby a State-based water-resources plan that provides for management of water is accredited under Section 63- or adopted under Section 69. 


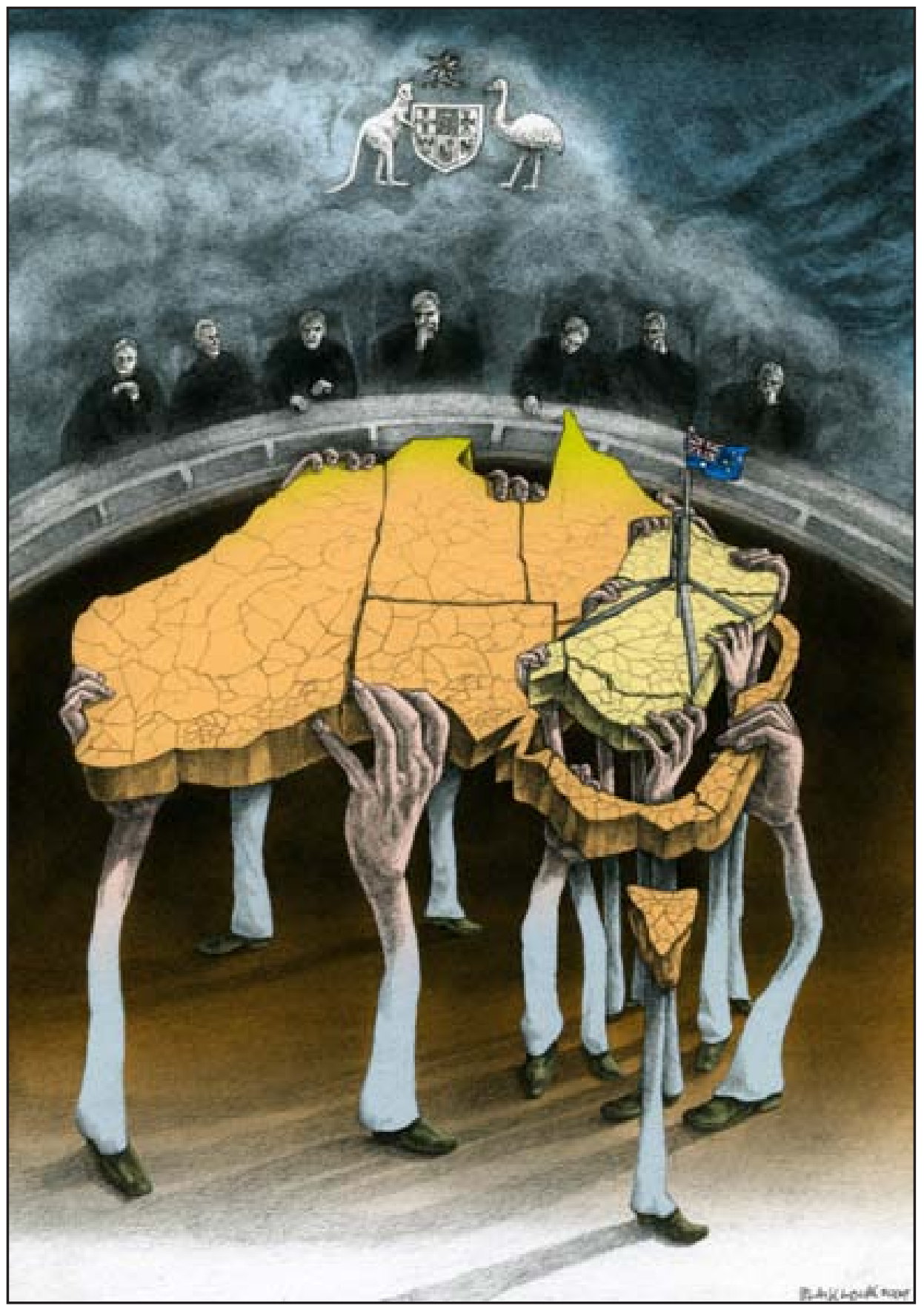

Figure 13.1 The Water Act 2007 and the oversight of some basin planswhy not the entire country?

Note: Concept 2010 - Jennifer McKay, drawn by D Blaiklock, copyright held (one of two) 
The accreditation requires evaluation of the evidence used by the State to support the ultimate level of water that is deemed to be available. This will rehearse some of the above considerations, but in an administrative-law context in the first instance. There is potential for a contest on the scientific bases for the decisions and an examination of the consultation processes undertaken by the State when drafting the plan. Hence, there are multiple avenues for evidentiary assessments of the underlying documents.

With regard to adoption or non-adoption of a State plan, the reasons for the nonadoption decision would also need to be reasonable and this would incorporate administrative-law standards of fairness and natural justice at the suit of a State. All of this litigation would take place in the High Court and is likely to develop the rules of evidence.

\section{Legal Duty of Care: The national interest}

The national interest is not a well-litigated term in Australian law. It appears in the objects Clause (s. 3[a]). The objects of this Act are '(a) to enable the Commonwealth, in conjunction with the Basin States, to manage the Basin water resources in the national interest'.

If it is accepted that the SDL is in the national interest then the Commonwealth minister will need to give reasons for not accrediting or adopting a State plan if the reason is that the plan is not in the national interest. The minister could form a view that a plan in one region takes too much water and hence is not in the national interest.

If we accept that SDLs are in the national interest then evidence will need to be adduced by the minister to provide the reasonable grounds for the nonadoption or non-accreditation of the State plan. This will be a highly political question and hotly contested. The community in the Murray-Darling Basin is not static, and the individuals in it belong to a matrix of regional communities, occupational associations and socioeconomic segments. The reaction to the Basin Plan shows that social change does not come about just by government decree but depends on changes in human relationships among individuals (Saunders 1999). The socio-political question could be stated thus: will the plan transform the ESD dictate into a popular national belief? The early hostile reactionsincluding the public burning of the Guide in New South Wales - suggests that the process to transform ESD into a national belief has a long way to go.

One final point on the national aspect of the test: in law, the national aspect may apply only to a region, but politically this will prove very difficult. Growers in half of Victoria will be subject to the national interest test and the rest merely subject to State laws. This will mean two sets of rules and will increase community angst. 


\section{The Legal Standard of Care: Relevant international agreements}

Section 21 provides the general basis on which the Basin Plan is to be developed. The Water Act directly incorporates several relevant treaties and makes allowance for inclusion of others by the term 'relevant'. It is unlikely that relevance will provide much cause for legal dispute; however, this direct incorporation of the treaties brings Section $15 \mathrm{AB}(2)$ (d) of the Acts Interpretation Act 1901(Cwlth), which permits recourse to 'any treaty or other international instrument that is referred to in the Act' $^{\prime}$ as extrinsic material that may be used to confirm the ordinary meaning of the text (s. $15 \mathrm{AB}[1][\mathrm{a}]$ ) or where there is ambiguity or the ordinary meaning would lead to an absurd result (s. 15AB[1][b]). Clearly, what is not considered ambiguous will be an issue in specific cases and this will cause evidentiary issues to arise.

Apart from the treaties listed, there are two texts of relevance: the UN Convention on the Non-Navigational Uses of International Watercourses 1997 and the 2010 UN International Law Commission Law of Transboundary Aquifers. McCaffrey (2010) has long argued that the 1997 Convention is customary international law and hence applies to all nations.

In the drafting of the Water Act, the 1997 Convention was not referred to at all, although many of the concepts in the 1997 Convention do accord with ESD. The 1997 Convention and the Transboundary Aquifer law include an innovative topic, and it is suggested that the Water Act include this. The concept covers the general duty to cooperate. The general obligation it states in the transboundary aquifer rules is as follows:

Aquifer States shall co-operate on the basis of sovereign equality, territorial integrity, sustainable development, mutual benefit and good faith in order to attain equitable and reasonable utilization and appropriate protection of their transboundary aquifers or aquifer systems. States are enjoined to establish joint mechanism of cooperation. (Article 7)

It is recognised that treaties may have an indirect impact on domestic Australian law prior to their implementation (such as in the Teoh case), therefore the above documents could also have an impact. Irrespective of the debatable position in law, the concept of joint cooperation mechanisms is sound and could arise in a de facto sense through the creation of the Basin Plan. 


\section{Conclusions}

This chapter has outlined some of the key issues where the social conflicts over the potential Murray-Darling Basin Plan are likely to reach a court for judicial settlement. This will bring with it a host of evidentiary issues related to the best available science and the concepts of national interest, and the ambiguity in these words might fail to be guided by international standards. Clearly, some sectors of the community think the plan has emphasised the environment too much, while others hold the opposite view.

When cases actually come to the High Court, some of these ambiguities will be settled, but the conflict-resolution processes will not end there, as it is always possible to change the Act in the event of too much social conflict. At the moment, it seems that the sustainability duty of care is being tested on the Australian community over this period (until 2012) (AAP 2010), and stakeholder views are to be considered in the new final Plan. One way to assist this would be to highlight the importance of cooperation over the management of shared basin resources and to outline and study examples of cooperative arrangements.

\section{Bibliography}

Australian Associated Press (AAP) 2010, 'Basin authority needs more time for plan', The Age, 2 November 2010.

Commonwealth of Australia 2004, Intergovernmental Agreement on a National Water Initiative, Commonwealth of Australia, Canberra.

Council of Australian Governments (COAG) 1994, Water Resources Policy Communique and Report of the Working Group on Water Resources Policy, Council of Australian Governments, Canberra.

Dietz, T. and Stern, P. C. 1998, 'Science, values and biodiversity', BioScience, vol. 48, pp. 441-4.

Edmond, G. 1998, "Negotiating the meaning of a "scientific" experiment during a murder trial and some limits to legal deconstruction for the public understanding of law and science', Sydney Law Review, vol. 20, no. 3, p. 361.

Edmond, G. and Mercer, D. 1997, 'The secret life of (mass) torts: the "Bendectin Litigation" and the construction of law-science knowledges', University of New South Wales Law Journal, p. 666-706.

Gunningham, N. and Sinclair, D. 2010, 'Water efficiency plans', Policy and Practice, vol. 27 EPLJ, p. 331. 
Hassan, F. A. 2010, Water history for our times, IHP Essays on Water History No. 2, International Hydrological Programme, UNESCO, Paris.

International Law Commission (ILC) 2010, Law of Transboundary Aquifers, International Law Commission, United Nations, New York.

Ker, P. 2010, 'Murray Darling back flip', The Age, 27 October 2010.

McCaffrey, S. 2010, Sovereignty and Cooperative Management of Shared Water Resources in a Time of Shrinking Availability: The role of international law in ISARM 2010 transboundary aquifers - challenges and new directions, 6 December 2010, UNESCO, Paris.

McKay, J. 2010, 'Some examples of the integration of environmental, economic and social considerations into decision making: the jurisprudence of facts and context', in D. Freestone and M. Nijhoff (eds), Legal Aspects of Sustainable Development. Volume 7, Leiden, Boston.

Murray-Darling Basin Authority (MBDA) 2010, Guide to the proposed Basin Plan, Murray-Darling Basin Authority, Canberra.

Saunders, H. H. 1999, A Public Peace Process Sustaining Dialogue to Transform Racial and Ethnic Conflicts, Palgrave, New York.

Sullivan, P. J., Acheson, J. M., Angermeier, P. L., Faast, T., Flemma, J., Jones, C. M., Knudsen, E. E., Minello, T. J., Secor, D. H., Wunderlich, R., and Zanetell, B. A. (2006). 'Defining and implementing best available science for fisheries and environmental science, policy and management.' Fisheries Vol 31(9), pp. 460-465.

The Age 2010, 'NSW farmers want Murray water plan pulled', The Age, 27 October 2010.

Tomlinson, M. and Davis, R. 2010, 'Integrating aquatic science and policy for improved water management in Australia', Marine and Freshwater Research, vol. 61, pp. 808-13.

United Nations 1997, United Nations Convention on the Law of the NonNavigational Uses of International Watercourses, UN Doc. A/Res/51/229, United Nations, New York.

\section{Cases}

Elandes Nominess Pty Ltd vs Minister for Water Resources [2002] SAERDC 130

Harvey \& Anor vs Minister Administering the Water Management Act 2000 [2008] NSWLR 165.

Teoh vs Minister for Immigration, Local Government and Ethnic Affairs (1994) 121 ALR 436 at 443 